
qualitative meta-synthesis. Consumer Behavior Review, $4(3), 290-308$.

ISSN: 2526-7884

Editor: Prof. Dr. Marconi Freitas da Costa Journal's e-mail: cbr@ufpe.br
Evaluation: Double blind review

Received: April 13, 2020

Accepted: August 20, 2020

\title{
COMPREHENDING VEGAN IDENTITY CONSTRUCTION THROUGH CONSUMPTION: A QUALITATIVE META-SYNTHESIS
}

\author{
Compreendendo a Construção da Identidade Vegana por meio do Consumo: Uma metassíntese \\ qualitativa
}

\author{
Lidiane Cecília Rodrigues Paiva ${ }^{1}$ \\ ORCID: http://orcid.org/0000-0002-8330-3765 \\ E-mail: lidiane.paiva@ufv.br \\ Gilberto Venâncio Luiz ${ }^{1}$ \\ ORCID: http://orcid.org/0000-0003-4826-2571 \\ E-mail: gilberto.luiz@ufv.br \\ ${ }^{1}$ Universidade Federal de Viçosa, Rio Paranaíba, Brazil
}

\begin{abstract}
This article aims to comprehend vegan identity construction through consumption. For this, a meta-synthesis of the accomplished results was made. It was conceived according to Sandelowski and \& Barroso (2006) model, in order to compile the results into a grounded theory. As the analyses were complete, a theoretical model composed by eight microcategories and a central category was assembled. Results showed that reflection about consumption is one of the primordial factors on vegan identity construction, since this lifestyle imposes to its supporters the need to act consciously towards their purchase actions. In addition, it is by means of these
\end{abstract}

\begin{abstract}
0 presente artigo tem por objetivo compreender a construção da identidade vegana através do consumo. Para isso, foi desenvolvida uma metassíntese dos estudos encontrados. Isto sendo feito conforme o modelo de Sandelowski e Barroso (2006), de forma a compilar os resultados em uma teoria fundamentada (Grounded Theory). Feitas as análises, chegou-se a um modelo teórico composto por oito macrocategorias e uma categoria central. Os resultados revelaram que a reflexão sobre o consumo é um dos fatores primordiais na construção da identidade vegana, visto que esse estilo de vida impõe aos seus adeptos a necessidade de
\end{abstract}


actions that the defended ethic and moral considerations are converted into practical actions. Therefore, it is observed that reflection and consumption behavior are responsible for differentiating the vegan public from the others and what allows the construction and affirmation of its identity.

Keywords: Meta-synthesis; Veganism; Consumption; Identity Construction. agir conscientemente perante as suas ações de compra. Ademais, é por meio dessas ações que as considerações éticas e morais defendidas são transformadas em ações práticas. Logo, observa-se que a reflexão e a maneira de consumir é o que diferencia o público vegano dos demais e que permite a construção e afirmação da sua identidade.

Palavras-Chaves: Metassíntese; Veganismo; Consumo; Construção de Identidade.

This work is licensed under a Creative Commons Attribution 4.0 International License.

\section{INTRODUCTION}

Consumption is part of society's daily routines and it will continue this way, regardless of its magnitude. The act of consuming is commonplace to all people and has direct influence on the establishment of several groups, besides being responsible for culturally reshaping a society (Kaminski, 2010). Taking into account this group constitution, it is noted that there is an association between culture, consumption and identity construction, and this has been a subject of interest of an increasing number of consumer behavior researchers (Pereira, Ayrosa \& Ojima, 2006).

Consumption practices can be seen as channels of participation and construction of local, collective or individual identities, with the consumed object acting as an identity highlighter. Consumption is not a shapeless act of desire, it is an arena to express identity and social attributes relations, such as status and beliefs. Therefore, consumption must be understood as a creative interaction between production logic, merchandise circulation and consumers' culturally molded identities, social positon, desires and perceptions (Rocha-Pinto, 2006).

In Brazil, a fast-growing group of consumers in the last few years are vegans, people who do not utilize products that are originated from or are a result of animal exploitation. According to data from Brazilian Vegetarian Society (SVB, 2019), the country has $14 \%$ of its total population composed of vegetarians. These statistics indicate a 75\% increase if compared to the year of 2012, when a research indicated that $8 \%$ of Brazilians in metropolitan regions declared themselves vegetarians, representing almost 30 million of the population of the country.

Moreover, it is important to note that, according to the SVB (2020), vegetarianism is considered a type of diet, in which the consumption of all types of meat is banned. It can be divided into four subgroups, which are: a) ovolactovegetarianism: makes use of eggs, milk and dairy products; b) lactovegetarianism: makes use of milk and dairy products; c) ovovegetarianism: makes use of eggs; d) strict vegetarianism: does not use any animal products in its diet. According to The Vegan Society (2020), veganism is a movement that goes further by seeking to eliminate all types of products, not just food, which are of origin or fruit of exploitation and animal cruelty.

Still according to SVB (2019), there are no studies in Brazil regarding the number of vegans. However, it can be taken into account the vegan percentage (among vegetarians) in other countries, such as the USA, where $50 \%$ of vegetarians declare themselves vegans and the UK, where about $33 \%$ of the vegetarians do the same. Thus, it can be estimated for Brazil, employing a conservative percentage (33\%), that within the 30 million brazilian vegetarians, around 7 million would be vegan. Such evidences are representative of a mentality change concerning consumption.

Nonetheless, despite the evidences of vegan market growth, few scientific papers have been dedicated to the study of these consumers. Research using international and national databases resulted in only 11 papers on the relations between Veganism, Consumption, Culture and Identity Construction. This research was done on Science Direct, Emerald Insight, Web of Science, Spell, Taylor \& Francis Online and on Capes Periodicals portal. Other papers were also found, but were not aligned with the theme of this research. Some approached sociological analysis and most of them focused on health and nutrition. Somehow, the papers run through vegan consumption and identity construction, 
but do not deepen on the subject. It is worth mentioning that the explanations about the criteria adopted to search for works will be presented in section 3: Research Methodology.

Thus, based on the lack of studies that associate vegan identity construction with their consumption behavior, this paper aims to display, through a meta-synthesis of the few scientific studies that approach the subject, how this relation is presented. This project will have as a basis both the model and parameters suggested by Sandelowski and Barroso (2006), in order to compile them into a Grounded Theory. Considerations done, in the following sections, specific elements of the study will be approached: theoretical foundation, research methodology, results and discussion and, by the end, conclusions and contributions obtained.

\section{THEORETICAL FOUNDATION \\ Identity Construction and Consumption}

There is a broad range of definitions for consumption and identity widespread, with no consensus about the definitions, yet, some deliberations about the subjects are necessary. To McCracken (2003), consumption is understood as the "procedures through which consumption assets and services are created, bought and utilized" (p.21). In consonace with this, Canclini (1999) states that consumption consists of "the group of sociocultural procedures in which are accomplished the appropriation and usage of products" (p.77). Therefore, consumption assets are imbued with cultural meanings and consumers employ these meanings to express and sustain their culture and lifestyle guiding principles (McCracken, 2003).

On the other hand, identity, according to Nunan (2003), can be defined as a set constituted of one's characteristics that represent one's "self", regarding a specific social situation. Therefore, identity concerns the insertion of an individual into a certain social category (such as race or sexual orientation). When displaced from the social situation that activates it, that identity can become latent. Thus, the identity is specific and the choice of the aspect to be expressed is motivated and influenced by the situation faced by the individual. Therefore, according to the author, the identity acquisition process occurs in a complex way and considering situations experienced by individuals, covering positive relations of inclusion and negative relations of exclusion.

Thus, it can be said that identity is acquired along an individual existence and it is built from the combination of two parts, one being inherent and personal, referring to one's individuality; and the other being something external that acts upon the individual. The external action executed by society dictates conduct rules and, from that, experiences are exchanged through conviviality, resulting in identity construction (Kaminski, 2010)

Moreover, Farias et al. (2019) propose that the understanding of the concept of identity spans five conceptual categories, namely: Fragmentation of Identity, Meaning of Goods, Extension of Identity, Group Identity and the Notion of Difference. Identity Fragmentation refers to the idea that the postmodern consumer has different identities that coexist and manifest at different moments. The Meaning of Goods refers to how people create and sustain their lifestyle and build the notion of themselves, with consumption structuring the reality and cultural context of which people are a part. An Extension of Identity is based on the propositions of Belk (1998), in which a group of goods is responsible for reflecting the identity of consumers. That way, the goods demonstrate the consumer's Self and are related to the creation and preservation of their sense of identity.

The Group Identity category reflects consumption practices that are related to the groups with whichthe consumer identifies, and only participants of the same group can understand the meaning of goods and their importance for the construction of identity. As a result, they may reveal stigmatized identities to individuals who are not part of the group. In the last category, Notion of Difference, the authors emphasize that consumers share identity characteristics and form similar groups and, on the other hand, deny those that are different (Farias et al., 2019).

On literature about culture and consumption, one of the focuses is on the relation between consumption and identity construction. In this sense, Slater (2002) argues that through the use of assets and services the individuals define themselves while carriers of personal and exclusive characteristics, which makes consumption a field for expression of the autonomy and privacy of the 
subjects. Therefore, he demonstrates that individuals' consumption behavior says a lot about who they really are, while active subjects on their identities construction. Agreeing with this, Farias et al. (2019) discourse that consumption helps creating identity and differentiation, based on the cultural context in which individuals are inserted.

According to Douglas and Isherwood (2004), individuals may use merchandise consumption to say something about themselves. Thus, the authors claim that merchandise are artifices employed on communication and differentiation of consumption practices and strategies on many social segments and their implications to habits e identities structuring. Similarly, Slater (2002) reports that on contemporary society, individuals' social relations occur around the pursuit of definition of their identities and consumption is the way chosen to define who they are and then build their identification towards society. Therefore, the act of consuming a certain product becomes an important way to communicate the expression of one's "self".

In the view of Dermody et al. (2018), the relationship between consumption and identity represents an integral component in the construction and improvement of individuals' self-identity. Self-identity being the combination of personal and social image that shows who the individuals were, who they are and who they may become in the future. Thus, the consumption of goods and services will help in the construction of individuals' self-identity and, consequently, of their social identity.

Belk (1988) argues that symbolic consumption can aid in categorizing oneself in relation to society. In addition, Belk (2010) states that consumers are what they have, since their goods represent an extension of their "self". Thus, when consuming certain goods, people can convince themselves that they have a certain identity towards society.

Gabriel and Lang (2006) also state that consumers have different faces and seek consumption to create their identity, so that, in order to express their individuality, they prefer to consume goods and services that they believe are able to represent who they are, thus demonstrating their personality, social position and personal values. In this way, contemporary consumers use goods opportunistically, that is, as a way of inferring and affirming an image about themselves. However, the authors point out that many consumers use resistance to the consumption of certain products as a means of communicating their identity.

Therefore, it is observed that the process of identity construction causes individuals to be divided into social groups, based on their habits and traditions. Thus, it is through consumption that people search, on products and brands, values that either differentiate them from some social groups or include them in a certain group, seeking, at the same time, differentiation and to stand out (Kaminski, 2010). Lastly, it is important to point out that construction is not something simple, taking into account that it is formed by a large set of elements, where there is a wide array of "pieces" that fit and complement each other, creating the whole, that is, shaping the identity of each person and group of people.

\section{Veganism}

Vegans are people with a well-defined positioning against any kind of animal cruelty and exploitation. According to The Vegan Society, a society that represents the oldest movement in the world, veganism can be defined as:

a philosophy and way of living which seeks to exclude - as far as is possible and practicable - all forms of exploitation of, and cruelty to, animals for food, clothing or any other purpose; and by extension, promotes the development and use of animal-free alternatives for the benefit of animals, humans and the environment. In dietary terms it denotes the practice of dispensing with all products derived wholly or partly from animals (The Vegan Society, 2020). 
Thus, vegans are not individuals with only a vision for eliminating the consumption of animaloriginated food, such as meat, milk or eggs. They are also contrary to forced labor involving animals and to the usage of cosmetics, clothes and cleaning material from the same kind of source. Furthermore, vegans oppose to the usage of animals in laboratories or in favor of the so-called science progress and any kind of entertainment that employs exposition/mistreatment, such as zoos, circuses, bullfights, rodeos, among others (Trigueiro, 2013).

So, the vegan proposition comes up based on an ethic and moral reframing, in order to fight against speciesism and any kind of animal exploitation (Trigueiro, 2013). It is important to highlight that speciesism consists of a discriminatory vision of other species, based on the presumption that the human animal is superior to other animal species. According to Singer (2010), this violates the principle of equality between beings, considering that speciesists defend the realization of their interests, even if it means overlapping those of other species.

Starting from the premise of the relationship of human/animal exploration in force in the world, the role of the media as a disseminating and affirming agent of the speciesist culture is highlighted. According to Acevedo et al. (2019), the media act in order to manipulate individuals through the dissemination of information that essentially seeks to encourage consumption. Therefore, information disseminated in the major media is intended solely to foster consumerist ideology and, for this purpose, disregards the welfare of animals and of the entire planet.

Moreover, Lundahl (2020) highlights that, even when the vegan proposal is presented by the media, it is done disregarding the political nature and the struggle for animal rights that characterizes the essence of the movement. He also highlights the role of celebrities and the media in spreading veganism as just another diet, that is, as a vehicle that promotes health and weight loss, nothing more than that. Doing that, the media only end up boosting consumerism, as they present a new diet, without going against the speciesist logic experienced. Therefore, the stigmatization of the movement's political and moral nature is still maintained.

Another important point is that veganism can be considered a kind of modern activism. The social acting of its supporters differs from the traditional models of political organization, getting itself closer to a life policy (Trigueiro, 2013). This in the sense that veganism involves, a priori, subjectivation processes, in which individuals reflect on their way of life considering philosophical, ethical and moral issues and how these can, in fact, become effective actions. Therefore, veganism is considered a movement of dispositional resistance, as the individual resists to consumption by his own choice, being motivated by ethical and moral issues (Moreira \& Acevedo, 2015). Based on that, the group believes that choosing a vegan lifestyle is a daily demonstration of compassion and respect for animals.

Vegans advocate to boycott consumption at various levels of products that culminate in death or mistreatment of animals (Abonízio, 2013; Acevedo et al., 2019; Ribeiro, 2019). Thus, the boycott is an elementary principle of veganism that is affecting products and companies considered exploiters of animal life, thus becoming a boycott with ethical motivations of respect for the life and dignity of animals. Besides boycotting, vegans perform protests to spread their cause, like public space interventions with marches, shows, conferences, video production, texts and blogs (Abonízio, 2013; Acevedo et al., 2019).

Even though research on veganism is still incipient, it is important to bring some contributions already identified in the literature. Acevedo et al. (2019) identified that many of the individuals who became vegans already had a trajectory in vegetarianism, which had resulted from experiences in which the subjects had had direct contact with the suffering of animals. It was also realized that the main motivations for becoming vegan involve ethical and moral issues. Regarding the characteristic habits of the group, those related to food stand out, such as the need to learn how to prepare their own food, to read the labels before buying any product, among other habits. Also noteworthy is the movement to share their ideals in their living environments, such as at work.

Regarding the costs faced, Acevedo et al. (2019) show the emotional and social ones, which involve prejudice suffered, pressure from family and friends, in addition to jokes and jokes in poor taste, which means that, many times, vegans choose to reduce social interactions. In addition, another 
thing that the vegans researched consider to be barriers are the financial costs, as the supply of products and establishments that meet the needs of this new group is still low.

Similar to this, Ribeiro (2019) also highlights ethical and moral issues as the main motivations for individuals to become vegan. She also shows that the main impacts perceived by the subjects revolve around changes in their behaviors, such as the fact that they become more activists, consume consciously and eat healthier. These impacts reach the emotional and spiritual fields; in the perception of physiological changes, such as changes in weight; in social life, changing the way they start to see and how they influence other people; and, finally, mental impacts, such as an increase in empathy with all beings and a different perception of themselves and others.

Another important point presented in the literature is the obstacles that vegans face to assert their identities before other audiences, such as omnivores. According to Buttny and Kinefuchi (2020), the vegans, in an attempt to not seem extreme or critical when in the presence of omnivores, end up avoiding discussions about structural issues of the movement, such as the animal ethics agenda, and put veganism, most of the times, as an individual food choice. Thus, because vegans understand that they are part of a minority against the current carnism culture, they avoid discussions about part of their motivations to join the movement.

\section{Veganism in Brazil}

Regarding the vegan market in Brazil, Rosa and Staldoni (2016) report that, statistically, the number of vegans in the country is increasing. However, the portion of the population that knows the principles that guide this lifestyle is still small. In this sense, the internet has been having an important role in spreading veganism, with growing numbers of NGOs, portals, blogs, Facebook groups, among other ways that use social networks to spread veganism and animal rights.

According to SBV data (2019), in Brazil, there are about 240 vegan and vegetarian restaurants. Besides the increase in the offer of vegan dishes and snacks in non-vegetarian restaurants and snack bars. The brazilian market's growth is a reflex of the world trend. In the UK, there was a $360 \%$ increase in the number of vegans in the last decade (2005-2015) and in the USA, during that same period, the number of vegans has doubled.

Also according to SBV data (2019), brazilian supermarkets have increased the offer of vegan products, such as nuggets, ham, quibes, coxinhas, sausages, ice cream and creamy cheese. Besides that, SBV's vegan certification program also acts as a thermometer to measure such market growth. The "Vegan Stamp" certificate already contemplates over 1000 products of 100 brands. Most of these brands offer food products, although hygiene and cosmetic products considered vegan already exist (SBV, 2019).

\section{RESEARCH METHODOLOGY}

This research is characterized by its exploratory nature and the usage, essentially, of qualitative methods, in order to develop a meta-synthesis of the scientific studies found. According to Sandelowski and Barroso (2006), the meta-synthesis consists of a qualitative methodology that seeks systematic revision or integration of results about a specific domain, by phenomenology, ethnographies, grounded theories, among other techniques, in order to develop theoretical models and theorizations about the studied subject. The utilized method was composed of six stages, as show in the table below:

Table 1

Integrative Meta-synthesis Model

\begin{tabular}{c|l}
\multicolumn{1}{c|}{ Stages } & \multicolumn{1}{c}{ Activities } \\
\hline $1^{\text {st }}-$ Starting Questions & $\begin{array}{l}\text { - Definition of objectives: investigation question } \\
\text { and theoretical board; }\end{array}$ \\
\hline
\end{tabular}




\begin{tabular}{l|l}
\hline & $\begin{array}{l}\text { - Definition of the database to be utilized; } \\
\text { - Definition of inclusion and exclusion criteria; }\end{array}$ \\
$2^{\text {nd }}-$ Search Protocol & $\begin{array}{l}\text { - Data search and organization strategies; } \\
\text { - Selection of studies; } \\
\text { - Quality evaluation. }\end{array}$ \\
\hline $3^{\text {rd }}-$ Metadata & $\begin{array}{l}\text { - Data grouping system; } \\
\text { - Analysis of articles' metadata. }\end{array}$ \\
\hline $4^{\text {th }}-$ Meta-method & $\begin{array}{l}\text { - Comparison of investigation models; } \\
\text { - Methodologies of the studies. }\end{array}$ \\
\hline $5^{\text {th }}-$ Meta-theory & $\begin{array}{l}\text { - Analysis of the studies; } \\
\text { - Analysis of implications and theoretical } \\
\text { guidelines; }\end{array}$ \\
\hline $6^{\text {a }}-$ Meta-synthesis & $\begin{array}{l}\text { - Theory development. } \\
\text { - Higher theoretical comprehension; } \\
\text { - Conclusions about the generated theorization. }\end{array}$ \\
\hline
\end{tabular}

Source: Adapted from Sandelowski and Barroso (2006).

During the first stage of the project, the main objective of the meta-synthesis was defined, and consisted in identifying how vegan consumers build their social identity through consumption practices, using consumption, identity and veganism as guidelines. During the second stage, the search protocol of the studies was developed. Thus, a research using national and international databases was done, in order to map the papers that explored the veganism theme and its relations with consumption, culture and identity formation. The bases utilized were Science Direct, Emerald Insight, Web of Science, Spell, Taylor \& Francis Online and the Capes Periodicals portal. The results were obtained from the combination of the terms "veganismo", "consumo", "cultura", "identidade" and their equivalents in English, employing peer grouping on search fields of each portal. Therefore, the resulting pairs were: "veganismo e identidade", "veganismo e consumo", "veganismo e cultura", "veganism identity", "veganism consumption", "veganism consumer", "veganism culture" and "vegan identity. After the searches, 155 articles addressing the themes were obtained.

Due to the high number of results, inclusion and exclusion criteria were developed. Thus, inclusion criterion was to consider only articles that mentioned at least two of the four main keywords chosen for the search, either on the title, the abstract or the keywords, emphasizing the fundamental need for the selected papers to discuss aspects referring the vegans. Therefore, the inclusion criterion established that the articles mentioned the term "veganism" and any of the other three keywords previously presented. Besides that, all the articles that did not fit within the settled criterion were excluded.

Amongst the discarded articles, some approached sociological analysis, while most of them focused on people's health and nutrition. Others were also excluded, being: a) duplicated articles; b) articles that did not have all of their content disclosed; c) articles that covered only vegetarianism, but not veganism; d) quantitative articles. After the exclusions, 11 articles were kept, with all of them being fully read and having their quality evaluated. These studies will be presented on the results section.

Third and fourth stages consisted in the organization and analysis of metadata, objectives and methodology used in the articles. Fifth and sixth stages were dedicated to the analysis of the content of results and to the conclusions of the studies, besides the theoretical model elaboration. To substantiate the analyses and interpretations of the results, the coding process proposed by Strauss and Corbin (2008) was employed. This coding process is divided into three steps, summarized in the table below:

Table 2

Steps of the Grounded Theory

\begin{tabular}{c|l}
\hline \multicolumn{1}{c|}{ Steps } & \multicolumn{1}{c}{ Activities } \\
\hline \multirow{2}{*}{$1^{\text {st }}-$ Open coding } & $\begin{array}{l}\text { - Categorize data obtained from the studies in } \\
\text { a list of codes and categories (or families, as }\end{array}$ \\
\hline
\end{tabular}




\begin{tabular}{l|l}
\hline & they are called on the software used); \\
\hline $2^{\text {nd }}-$ Axial coding & $\begin{array}{l}\text { - Group the categories (or families) into more } \\
\text { specific categories; } \\
\text { - Specify and refine the existing relations } \\
\text { between categories; }\end{array}$ \\
\hline $3^{\text {rd }}-$ Selective coding & $\begin{array}{l}\text { - Elaborate the essencial category, that is, the } \\
\text { category that covers the central phenomenon; } \\
\text { - Integrate all the categories with the central } \\
\text { category. }\end{array}$ \\
\hline
\end{tabular}

Source: Elaborated by the authors, based on Strauss and Corbin (2008).

Lastly, in order to help with the analysis of the content and with the meta-synthesis elaboration, it was used the software Atlas/ti 8.0, application developed solely as an aid to the analysis of qualitative data. Its usage was essential to the coding, organization and formulation procedures of the resulting theoretical model. However, it is worth mentioning that the software itself does not perform any analysis procedure, only acting as a supporting tool for data organization and interpretation.

\section{RESULTS AND DISCUSSION \\ Characterization of the Studies}

It can be noted in the table below the titles, authors and pairs of keywords used during the search as well as the countries and places where the 11 articles analyzed were originally written and published. Here, it is important to point out that a numbering system was adopted in order to facilitate the identification of the studies, in a way that the reader knows how to identify to which study the excerpts to be presented in the next section (Meta-theoretical Model).

Table 3

Characterization of studies I

\begin{tabular}{|c|c|c|c|c|c|}
\hline Study & Title & Authors & $\begin{array}{c}\text { Keywords } \\
\text { used during } \\
\text { the search }\end{array}$ & Publisher & Country \\
\hline 1. & $\begin{array}{l}\text { Celebrity vegans and the } \\
\text { lifestyling of ethical } \\
\text { consumption }\end{array}$ & Julie Doyle & "vegan identity" & $\begin{array}{l}\text { Taylor \& } \\
\text { Francis Online }\end{array}$ & UK \\
\hline 2. & $\begin{array}{l}\text { Consumo alimentar e } \\
\text { anticonsumismo: veganos } \\
\text { e freeganos }\end{array}$ & Juliana Abonizio & $\begin{array}{l}\text { veganismo e } \\
\text { consumo }\end{array}$ & $\begin{array}{l}\text { Periódicos da } \\
\text { Capes }\end{array}$ & Brazil \\
\hline 3. & $\begin{array}{l}\text { Consumo, ética e natureza: } \\
\text { O veganismo e as } \\
\text { interfaces de uma Política } \\
\text { de Vida }\end{array}$ & Aline Trigueiro & $\begin{array}{l}\text { veganismo e } \\
\text { identidade }\end{array}$ & $\begin{array}{l}\text { Periódicos da } \\
\text { Capes }\end{array}$ & Brazil \\
\hline 4. & $\begin{array}{l}\text { Exploring veganism } \\
\text { through serious leisure } \\
\text { and } \\
\text { liquid modernity }\end{array}$ & $\begin{array}{l}\text { Gracie DaSilva; } \\
\text { Juliette Hecquet; } \\
\text { Katherine King }\end{array}$ & "vegan identity" & $\begin{array}{l}\text { Taylor \& } \\
\text { Francis Online }\end{array}$ & UK \\
\hline 5. & $\begin{array}{l}\text { Normalizing ideological } \\
\text { food choice and eating } \\
\text { practices. Identity work in } \\
\text { online } \\
\text { discussions on veganism }\end{array}$ & $\begin{array}{l}\text { Petra Sneijder; } \\
\text { Hedwig Te } \\
\text { Molder }\end{array}$ & $\begin{array}{l}\text { "veganism } \\
\text { identity" }\end{array}$ & Science Direct & Netherlands \\
\hline 6. & $\begin{array}{l}\text { Veganism as a Cultural } \\
\text { Movement: } \\
\text { A Relational Approach } \\
\end{array}$ & Elizabeth Cherry & "vegan identity" & $\begin{array}{l}\text { Taylor \& } \\
\text { Francis Online }\end{array}$ & $\begin{array}{l}\text { United } \\
\text { States }\end{array}$ \\
\hline 7. & $\begin{array}{l}\text { Realidades e imagens do } \\
\text { especismo: impactos da }\end{array}$ & $\begin{array}{l}\text { Anabela Santos; } \\
\text { Rui Pedro }\end{array}$ & $\begin{array}{l}\text { veganismo e } \\
\text { consumo }\end{array}$ & $\begin{array}{l}\text { Periódicos da } \\
\text { Capes }\end{array}$ & Spain \\
\hline
\end{tabular}




\begin{tabular}{|c|c|c|c|c|c|}
\hline & $\begin{array}{l}\text { indústria (agro)pecuária e } \\
\text { representações } \\
\text { publicitárias de animais } \\
\text { não-humanos sencientes }\end{array}$ & Fonseca & & & \\
\hline 8. & $\begin{array}{l}\text { Resistência ao consumo e } \\
\text { Veganismo: Um Estudo } \\
\text { sobre as Motivações, } \\
\text { Valores e Sentimentos }\end{array}$ & $\begin{array}{l}\text { Isabela Perez } \\
\text { Campos Moreira; } \\
\text { Claudia Rosa } \\
\text { Acevedo }\end{array}$ & $\begin{array}{l}\text { veganismo e } \\
\text { consumo }\end{array}$ & Spell & Brazil \\
\hline 9. & $\begin{array}{l}\text { "If I became a vegan, my } \\
\text { family and friends would } \\
\text { hate me:" Anticipating } \\
\text { vegan stigma as a barrier } \\
\text { to plant-based diets }\end{array}$ & $\begin{array}{l}\text { Kelly L. } \\
\text { Markowski; } \\
\text { Susan Roxburgh }\end{array}$ & $\begin{array}{l}\text { "veganism } \\
\text { identity" }\end{array}$ & Science Direct & $\begin{array}{l}\text { United } \\
\text { States }\end{array}$ \\
\hline 10. & $\begin{array}{l}\text { Veganism, Identity and the } \\
\text { Quest for Authenticity }\end{array}$ & $\begin{array}{l}\text { Jessica } \\
\text { Greenebaum }\end{array}$ & $\begin{array}{l}\text { "veganism } \\
\text { identity" }\end{array}$ & $\begin{array}{l}\text { Web of } \\
\text { Science }\end{array}$ & $\begin{array}{l}\text { United } \\
\text { States }\end{array}$ \\
\hline 11. & $\begin{array}{l}\text { Vegetarianism, Veganism, } \\
\text { and Meat Avoidance: } \\
\text { Recent Trends and Finding }\end{array}$ & $\begin{array}{l}\text { A.D. } \\
\text { Beardsworth; } \\
\text { E.T. Keil }\end{array}$ & $\begin{array}{l}\text { "veganism } \\
\text { consumer" }\end{array}$ & $\begin{array}{l}\text { Emerald } \\
\text { Insight }\end{array}$ & UK \\
\hline
\end{tabular}

Source: Search data.

According to what was presented, three of the studies were selected from the Capes Periodicals Portal, one from Spell, two from Science Direct, one from Web of Science, one from Emerald Insight and three from the Taylor \& Francis Online portal. In the following table, it is possible to note a brief introduction of objectives and methodology used for each of the articles.

Table 4

Characterization of studies II

\begin{tabular}{|c|c|c|}
\hline Study & Objectives & Methodology \\
\hline 1. & $\begin{array}{l}\text { To question how the role of cultural } \\
\text { intermediate of vegan celebrities can make } \\
\text { the ethical practice of veganism more } \\
\text { accessible. And also how vegan concerns } \\
\text { about the production and consumption of } \\
\text { food and other products derived from } \\
\text { animal exploitation are reformulated } \\
\text { within the celebrities' consumption culture. }\end{array}$ & $\begin{array}{l}\text { The study gathered ethical veganism and } \\
\text { ecofeminism philosophies with literature } \\
\text { about ethical consumption (of food) and } \\
\text { celebrities' culture, in order to analyze the } \\
\text { efforts of educational campaign about } \\
\text { veganism under the perspective of two } \\
\text { celebrities, Alicia Silverstone and Ellen } \\
\text { DeGeneres. }\end{array}$ \\
\hline 2. & $\begin{array}{l}\text { To analyze veganism and freeganism while } \\
\text { lifestyles provided by consumption society. }\end{array}$ & $\begin{array}{l}\text { Article of theoretical nature, supported by } \\
\text { themes such as: consumption, counterculture } \\
\text { and lifestyle. }\end{array}$ \\
\hline 3. & $\begin{array}{l}\text { To analyze the vegan movement from three } \\
\text { specific points: its flag (types of activism } \\
\text { and political action); the ethical postulate } \\
\text { inherent to its claims (philosophical basis) } \\
\text { and the lifestyle required from its adepts } \\
\text { (consumption practices). }\end{array}$ & $\begin{array}{l}\text { The article used a theoretical background as } \\
\text { well as an empirical approach: internet } \\
\text { searches, through mapping and investigation } \\
\text { of admittedly vegan groups and forums } \\
\text { directed to animal rights and veganism } \\
\text { discussions. }\end{array}$ \\
\hline 4. & $\begin{array}{l}\text { To explore veganism as a way to seek } \\
\text { serious recreation within the context of } \\
\text { Liquid Modernity. }\end{array}$ & $\begin{array}{l}\text { The study used semi-structured interviews, } \\
\text { carried out in } 2017 \text {, having as theoretical } \\
\text { support the perspective of serious leisure. }\end{array}$ \\
\hline 5. & $\begin{array}{l}\text { To explore the relation between choice of } \\
\text { food based on ideology and people's } \\
\text { identities. }\end{array}$ & $\begin{array}{l}\text { It had as support the usage of discursive } \\
\text { psychology, in order to analyze data collected } \\
\text { from discussions of an online forum about } \\
\text { veganism. }\end{array}$ \\
\hline 6. & $\begin{array}{l}\text { To explore ways of participation in diffuse } \\
\text { cultural movements, through the vegan } \\
\text { movement. }\end{array}$ & $\begin{array}{l}\text { It adopted a relational approach of data, } \\
\text { employing ethnographic semi-structured } \\
\text { interviews conducted with vegans from two } \\
\text { different groups (punks and not punks). The }\end{array}$ \\
\hline
\end{tabular}




\begin{tabular}{|c|c|c|}
\hline & & $\begin{array}{l}\text { interviews had lengths varying from ninety } \\
\text { minutes to two hours. }\end{array}$ \\
\hline 7. & $\begin{array}{l}\text { To reveal the impacts of the agriculture } \\
\text { industry on enviroment and on human } \\
\text { health; to analyze the } \\
\text { objetification/fragmentation of sentient } \\
\text { non-human animals before the act of } \\
\text { consumption; to analyze advertising images } \\
\text { that demonstrate how speciesism is } \\
\text { presented by the media. }\end{array}$ & $\begin{array}{l}\text { The article analyzed advertising images with } \\
\text { non-human animals, based on Kress and Van } \\
\text { Leeuwen's sociosemiotic approach (1996). }\end{array}$ \\
\hline 8. & $\begin{array}{l}\text { To analyze the behavior related to anti- } \\
\text { consumption and try to identify and } \\
\text { comprehend the motivations, values and } \\
\text { feelings behind the resistance to } \\
\text { consumption. }\end{array}$ & $\begin{array}{l}\text { The study used the ethnographic method to } \\
\text { collect and analyze data, considering that the } \\
\text { sample group was observed and analyzed } \\
\text { using participant observation and deepened } \\
\text { interviews. }\end{array}$ \\
\hline 9. & $\begin{array}{l}\text { To discuss the perceptions about veganism } \\
\text { and vegans with omnivores, vegetarians } \\
\text { and vegans. }\end{array}$ & $\begin{array}{l}\text { Five separate focal groups were made, during } \\
\text { the year of } 2015 \text {, containing vegetarian, } \\
\text { vegan and omnivore college students. }\end{array}$ \\
\hline 10. & $\begin{array}{l}\text { To investigate how about sixteen ethical } \\
\text { vegans deal with the difficulties of living in } \\
\text { a society moved by animal-based } \\
\text { consumption. }\end{array}$ & $\begin{array}{l}\text { The article used deepened qualitative } \\
\text { interviews, conducted with volunteers } \\
\text { recruited through a website called } \\
\text { Meetup.com, used to connect people with } \\
\text { shared interests. All of the interviews were } \\
\text { transcribed and, after that, they were } \\
\text { analyzed. The author also used Goffman's } \\
\text { impression management theory and the } \\
\text { presentation of self. }\end{array}$ \\
\hline 11. & $\begin{array}{l}\text { To report the main conclusions of a } \\
\text { qualitative study detailing motivations, } \\
\text { beliefs and attitudes of vegetarian and } \\
\text { vegan practices. }\end{array}$ & $\begin{array}{l}\text { Semi-structured interviews were performed, } \\
\text { with lengths between one and two hours. All } \\
\text { of the interviews were transcribed and } \\
\text { analyzed. The sampling process involved the } \\
\text { snowball technique, with a total of } 76 \\
\text { participants. }\end{array}$ \\
\hline
\end{tabular}

Source: Search data.

According to the aforementioned information, all studies employed qualitative methods (requirement to develop a meta-synthesis), with semi-structured interviews being the most used method. Besides that, in general, all of them permeated aspects of veganism, as a way of establishing relations with consumption and identity construction.

\section{Meta-theoretical Model}

Following the previous steps of meta-synthesis construction, the process of study coding was performed. Starting with the open coding, through which, as presented in table 2, the content of the studies was grouped into codes and starting categories, called families by the software. During this first step, the basic procedures were comparing and questioning what was being read, in order to find similarities and differences between the contents (Strauss \& Corbin, 2008).

As a result, 303 codes were defined, and then clustered in 44 families (starting categories). These 44 families, during axial coding, which is the refining step of the initial categories, were regrouped into nine macrocategories. During the third and final step, called selective coding, the objective was to identify the essential category, that is, the central category, around which the others would be clustered and to which they would be integrated (Strauss \& Corbin, 2008). When the coding steps were concluded, the integration of categories showed a total of eight macrocategories interconnected to a central category. Next, the macrocategories that emerged from data and the resulting theoretical model are presented. 


\section{Perception About Being Vegan}

In this category are presented the codes and families that refer to the perception about being a vegan, that is, how vegans are comprehended by other groups, such as vegetarians and omnivores, besides the way they perceive themselves. Inside the model, this category can be understood as a context where the phenomenon occurs. Thus, according to Strauss and Corbin (2008), this context idea represents then a set of conditions belonging to the phenomenon, represented by the central category. According to this, it can be noted, through Figure 1 (presented on item 4.3), that the Perception About Being Vegan category is expressed through an association link with the central category, Vegan Identity.

The perception most non-vegans have about vegans has a negative connotation. Thus, vegans are perceived many times as being annoying, intolerant, invasive, aggressive militants and a series of other negative adjectives, all in the sense of saying vegans try in every way to impose their lifestyle to others. This can be confirmed through the following excerpt from study 9: ". . that vegans want to control and change their behavior ... that in order to continue their lifestyle, they kind of have to force people out of the way... They have to be kind of aggressive to keep it going" (Markowski \& Roxburgh, 2019, p. 5).

Regarding their food practices, vegan meals are seen as impractical, tedious and lacking basic nutrients. The non-vegans not only keep this negative perception, but they also anticipate the vegan stigma, that is, they believe that they would be ridiculed or treated ironically or if they became vegetarians.

On the other hand, the perception vegans have about themselves and other vegans is that they are happy, loving and conscious people. However, they also know that non-vegans do not perceive them in a positive manner. As it can be seen in the following excerpt from study 9:

The vegans were the only group that uniformly responded with positive descriptors when explaining how they view vegans and veganism. Keywords and phrases here included "aware," "openminded," "peaceful," "kind" and "loving." When the vegans listed negative descriptors, it was exclusively in the context of how vegans thought non-vegans viewed them and their ideas (Markowski \& Roxburgh, 2019, p.4).

This is in line with what was identified by Ribeiro (2019), because, in her findings, she verified that there is a change in the way that vegans perceive themselves and others. In addition, Buttny and Kinefuchi (2020) state that the way vegans are perceived by non-vegans sometimes causes vegans to end up avoiding discussions about what, in fact, the movement is. It is observed, then, that vegans are happy to be who they are, while non-vegans stigmatize and sometimes ridicule their behaviors and practices. Therefore, perceptions about being vegan are as varied as possible, as they act as a context in which the Vegan Identity is formed.

\section{Understanding Veganism}

In this category are gathered the codes that refer to the various perceptions about veganism. Inside the theoretical model, this category can also be understood as a context. In addition to this, it can also be noted through Figure 1 that the category Understanding Veganism is represented by an association link with the central category, Vegan Identity.

The analyzed studies approach multiple ways to comprehend what is, in fact, veganism, but, in general, everyone perceives veganism as a kind of movement that refers to a new lifestyle, more holistic and that proposes a new kind of relationship between human beings, animals and consumption. This can be noted in the following excerpt from study 4: "the research supports the concept of veganism allowing for a more holistic, philanthropic view, less tied to individual benefit, encompassing wider societal identity" (DaSilva, Hecquet \& King, 2019, p.14). 
Furthermore, study 6 states that "vegans represent a new form of social movement that is not based on legislation or political identity, but instead is based on everyday practices in one's lifestyle" (Cherry, 2006, p. 156). Otherwise, study 7 states: "the path towards more sustainable societies shall be done, then, by adopting vegan practices, because these are essential to reduce violence against nonhuman animals, protect the environment, to put a stop to food crisis and to promote public health" (Santos \& Fonseca, 2012, p. 220).

Therefore, it is observed that even with some variations, the understanding of what is veganism go against the concept of veganism enunciated by The Vegan Society (2020) and, in this way, it is noticed that they always retake the idea that the vegan movement represents a new way of thinking, being and acting, that is, it is a process of reframing everything that is considered common and normal to society. Thus, these ways of seeing veganism act as a context where Vegan Identity is built.

\section{Media Representations}

In this category are grouped the codes and families that refer to media representation about veganism. Inside the theoretical model proposed, this category belongs to the context of where the phenomenon occurs. It is also represented on Figure 1 with an association link to the central category, Vegan Identity.

Media representations act in order to encourage excessive consumption, disregarding animals, human beings and the whole planet's welfare. In addition to that, they hold a fundamental role of masking reality, that is, when portraying animals in tranquil environments and, most of the times, with essentially human-like characteristics (anthropomorphization), they hide the reality of violence and exploitation experienced by them. This can be seen in the excerpt below, from study 7:

The promotion of a speciesist social order happens, above all, through the media. They assure the massive production of consumption ideologies and give consistency to the social representations shared by social actors. Particularly, publicity is prone to portray sentient non-human animals as complicit in their own instrumentalization, promoting invisibility of the violence committed against them (Santos \& Fonseca, 2012, p. 219).

This corroborates what was identified by Acevedo et al. (2019) and Lundahl (2020), that the media manipulate the information that is transmitted through their transmission channels. In view of this, it is observed that the mainstream media act in order to affirm speciesism, that is, in order to subdue the sentience capacities of animals, placing them as submissive to human beings and conniving, even "happy", with the violence practices imposed on them. For this reason, media representations are seen as belonging to the context in which the Vegan Identity takes shape.

\section{Reflective Consumption}

In this category are clustered codes and families that refer to a reflection about consumption. Inside the theoretical model, this category can be understood as an intermediate condition for the phenomenon and, according to Strauss and Corbin (2008), it is seen as support for action/interaction strategies belonging to the phenomenon. In Figure 1 it is possible to observe that at the same time that reflective consumption belongs to Vegan Identity, it also acts as one of the causes of the Conversion Process.

In this sense, reflective consumption refers to the act of thinking about consumption and its impacts on daily life, that is, consuming consciously. As it can be seen in the following excerpt from study 3: "that said, the construction of a new vegan lifestyle demands from those engaged in this movement constant monitoring of their actions and practices, mainly in what concerns the consumption of food, clothes and products in general" (Trigueiro, 2013, p. 251). 
Reflection on consumption causes vegans to start looking for products that match their lifestyle. This reflection also makes them stop consuming products of animal origin or fruit of exploitation, this being considered the essence of vegans. Corroborating this view, Gabriel and Lang (2006) describe that consumers can stop consuming products so as to communicate their identity and demonstrate who they are. Thus, by not consuming this type of products, vegans are distinguished from other types of consumers.

So, this new way of consuming is related to veganism because it allows people to reflect on their buying behavior and make their choices taking into account ethical and moral issues. That is why, at the same time that reflective consumption belongs to Vegan Identity and helps assert this identity, it can also be considered one of the causes that lead to the Process of Conversion to the movement.

\section{Consumption and Identity}

In this category are gathered codes and families that refer to consumption and identity. Inside the proposed model it can be understood as a condition, effect or result of Vegan Identity. According to this, in Figure 1, it is possible to observe the type of relationship that exists between this category and the Vegan Identity. That said, it is ensured that it is through consumption that individuals have their identities shaped and assured. This can be noted in study 8, when it points that "we consume to satisfy our desires and not to satisfy essential human needs. It is through consumption that individuals assert their identities" (Moreira \& Acevedo, 2015, p. 52).

In addition, consumption becomes the cause of the assertion of vegan identity, since with the presence of this new group, it becomes necessary the production and offering of products that meet the new necessities. This can be exemplified by study 2, "although noticing the flexibility of contemporary identities, I highlight the demand of new products by specific groups, besides new means of production by those who adopt certain style" (Abonizio, 2013, p. 193). Therefore, it is noted that consumption acts represent a kind of "two-way street" to consumers, because these are capable of promoting change in production and, at the same time, it is through these products offered that individuals build and assert their identities.

To support their identity, vegan people use the goods and services they consume as a way of establishing, reinforcing and presenting their identity to other people. In their propositions, Gabriel and Lang (2006) argue that consumers, through the consumption of goods, demonstrate their personality and values. Corroborating this view, Farias et al. (2019) claim that through consumption people create and sustain their lifestyle. In this sense, the consumption of products that do not come from animal origin or exploitation can be considered a way for vegans to create, fix, sustain and represent their identity towards society. Therefore, this category acts as a condition, effect or result of the Vegan Identity.

\section{Facilitators and Barriers}

In this category are gathered codes and families that refer to facilitators and barriers to becoming vegan. Inside the model, it can be understood as a specific causal condition to the process of conversion to veganism. In addition to that, in Figure 1, it is clear that this category establishes a causal relation towards the Conversion Process.

Inside the facilitators are included: the process of knowing better what veganism is and what is its proposal; the elimination of vegan stigma, support from family and friends; the importance of a sense of belonging, in the sense of being part of some movement/group that also defends the same ideals; the increased offering of vegan products, besides a series of other cultural and economic elements. Furthermore, the motivations that lead someone to becoming vegan are crucial points to the conversion process.

The analyzed studies presented many motives, but, in general, they cover ethical and moral questions, such as the pursuit for justice and respect towards animals and the fight against speciesism; health matters, like avoiding the ingestion of meat due to its high levels of fat and hormones; taste issues, that is, not ingesting meat due to its flavor/texture; and, lastly, environmental issues, like concerns related to environmental exploitation because of cattle raising. 
In order to demonstrate how the facilitators are presented, some excerpts from the studies can be observed next. Study 1 directs its focus to health matters when it says that "Ellen's Healthy Living" main page prioritizes health approaches" (Doyle, 2016, p. 785). Study 9, on the other hand, emphasizes the importance of the support of close people as it says it is important to "have the support of family members and friends" (Markowski \& Roxburgh, 2019, p. 7). Study 3, differently, is targeted towards ethical and moral issues:

... findind a relatively solid set of arguments in favor of a social change that was used not only to the abolition of the Homo sapiens-centric speciesism, but to a reinterpretation of the moral principles that shape our western modern society (Trigueiro, 2013, p. 248).

Regarding the barriers to becoming vegan, they are: social judgment and the fear of the vegan stigma, negative reactions from relatives, preparation of food, the increased need to plan before going shopping, among others things. Besides all that, there are the emotional costs, in the sense that these people have become the targets of jokes and prejudice, and they suffer because of the tension resulting of conflicts with family and friends; the financial costs with the increase in expenses due to the high prices that are still charged for vegan products, besides their availability.

Next are shown some excerpts that present these barriers; study 8 says that ". . the main emotional, social and financial factors associated to the adoption of a vegan lifestyle are: prejudice, family and peer pressure, jokes, leading to isolation and avoidance of most social reunions" (Moreira \& Acevedo, 2015, p. 62). In addition to that, study 4 states that “... nothing is easily available... you have to actively search for vegan products... and that is annoying and frustrating. And it is also more expensive" (DaSilva et al., 2019, p. 10).

It is observed that these findings are in agreement with the contributions of Acevedo et al. (2019) and Ribeiro (2019), as both highlight the similar aspects arising from the adoption of a vegan lifestyle. Therefore, there are countless facilitators and barriers that the subjects face in the process of becoming and staying vegan, and this is greatly influenced by the motivating factors that lead individuals to choose or not to choose this lifestyle. Therefore, it is understood that this category acts as a cause for the Process of Conversion to veganism.

\section{Conversion Process}

In this category are clustered the codes and families that are part of the process of conversion of people to veganism. In the theoretical model, this category fit inside the action/interaction strategies that, according to Strauss and Corbin (2008), are strategies to deal with and respond to a certain phenomenon. In Figure 1 it is possible to observe that the process of conversion is considered part of the vegan identity.

That said, it is noted that the process of conversion to veganism involves veganism transition experiences that can occur gradually, as presented by study 11 :

The influence of primary contacts like relatives, friends and colleagues is crucial in this gradual process. Such contacts may influence through persuasion or example, and may not only initiate a move into vegetarianism, but also encourage a move to the right along the vegetarian scale (Beardsworth \& Keil, 1991, p. 21).

Or abruptly as in traumatic experiences, that involve, also according to study 11 "witnessing previously unseen aspects of animal husbandry, transportation or slaughter and, in some cases, sudden feelings of nausea or revulsion when confronted with or actually consuming meat" 
(Beardsworth \& Keil, 1991, p. 21). An interesting point is that vegetarians are prone to deal better with this process, since they already shared some practices with the vegan group.

This is linked to what was identified by Acevedo et al. (2019), as the authors also noticed a tendency and a greater ease for vegetarians to become vegans. In addition to the existence of a similar movement towards gradual conversion to vegetarianism, since individuals had direct contact with situations involving animal suffering. In short, this is why the experiences that involve the conversion process are considered ways of dealing with and responding to a certain phenomenon, which, in this case, is the Vegan Identity.

\section{Implications of Being Vegan}

In this category are grouped codes and families that are part of the implications of being vegan on contemporary society. In the theoretical model this category can be comprehended as a consequence of the phenomenon, which, according to Strauss and Corbin (2008), corresponds to the results of action/interaction strategies. Agreeing with that, it is possible to observe in Figure 1 the association link between this category and the conversion process.

The implications of being vegan include: modifications on work practices, in order to act more ethically towards animals and the environment; the feeling of being happier with yourself, noticing an improvement on physical and mental health; the acquisition of new knowledge and abilities, among other implications considered positive. In order to exemplify these positive implications, some excerpts are presented. Study 10 says that ". . her healthy diet and lifestyle negated the need of medicine, much to the surprise of her doctors" (Greenebaum, 2012, p. 140). Study 4 states that "... being vegan had influenced their work practices, adapting their work practices to be more ethical" (DaSilva et al., 2019, p. 11).

However, there are also difficulties related to "being vegan", some being: media, family and friends influence, the possibility of relapsing, besides having to deal with the physical and social detachment faced. Besides that, when it comes to health maintenance, most vegans do not see this issue as being bigger than that to which other individuals are exposed. This is presented in study 5 :

[...] it was shown how the prevention of (future) health problems was presented as a routine practice involving mundane and simple actions. The notion that vegans have to put more effort into health control than any other human being with 'normal' eating practices was thus undermined (Sneijder \& Molder, 2009, p. 628).

Therefore, it is observed that there are several implications resulting from being vegan. In general, most of these implications are seen as positive by the supporters of the movement, with emphasis on the fact that they become more activists, consume consciously and eat healthier, aspects also identified by Ribeiro (2019). However, many of these implications come to be understood as difficulties when it comes to dealing with those who are not vegan. This causes, according to Buttny and Kinefuchi (2020), structural issues of the movement to be left out; moreover, according to Acevedo et. al (2019), it can also cause vegans to reduce their social interactions. Thus, the implications of being vegan are considered consequences, that is, results of Vegan Identity.

\section{Comprehending Vegan Identity Construction by Consumption}

This item aims to presenta comparison of the central category, the central hypothesis and the meta-theory propositions about how vegans construct their identity through consumption. Ergo, in Figure 1 it is shown how the central category and the macrocategories are linked to each other.

It is observed that Vegan Identity represents the central category of the theoretical model that results from the meta-synthesis integration process. This vegan identity covers a new lifestyle, which is built as a project and rather than as something momentary and ephemeral. In addition, as theorized by McCracken (2003), consumption assets acquired by vegan people are meaningful and these 
consumers use them as a way to spread and support the guiding principles of their lifestyle. Furthermore, this style covers new ways of consuming, working, feeding; in other words, it is the general reframing of values and practices that bring up the relationship "humans/animals".

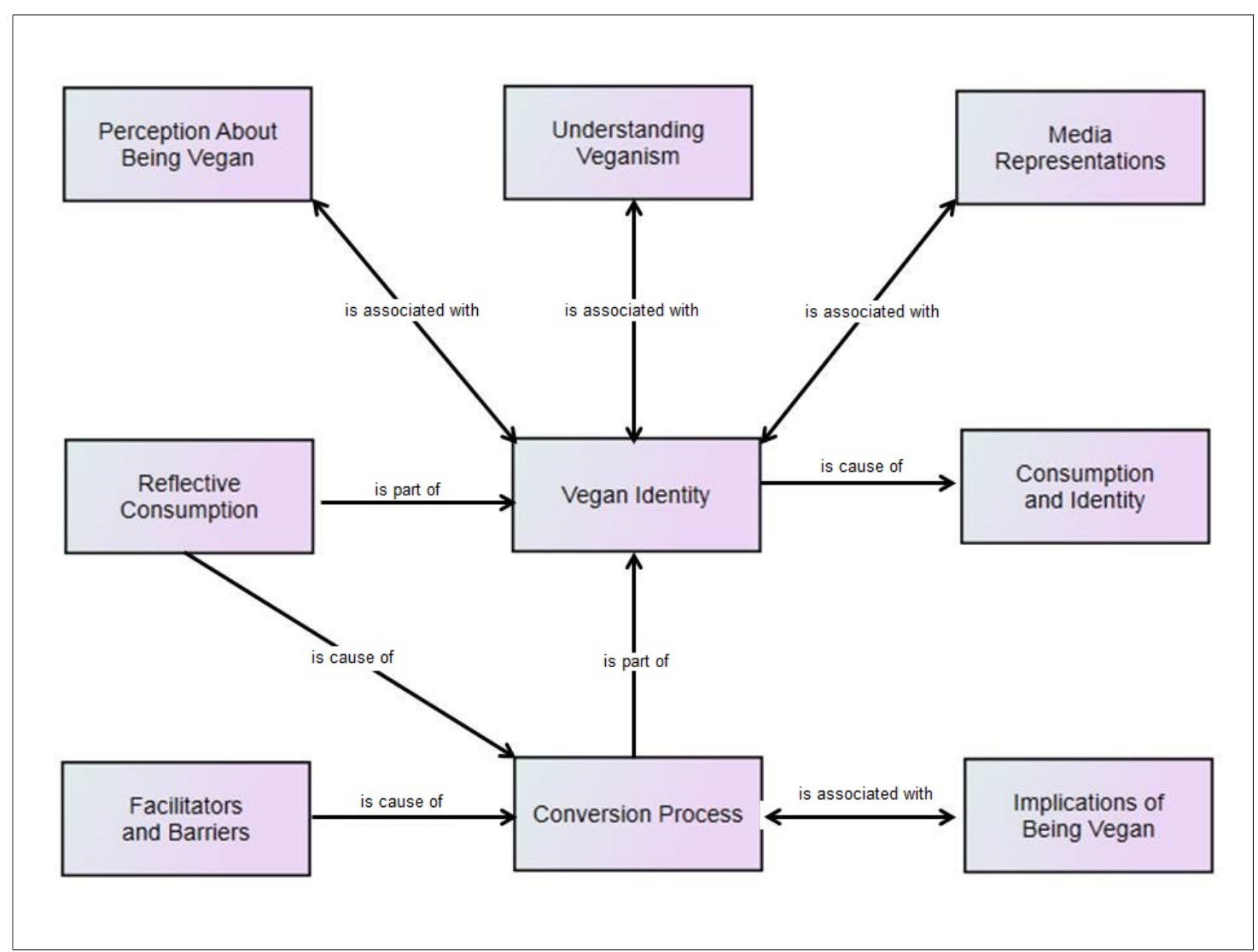

Source: Elaborated by authors.

Figure 1: Resulting model from the integration of results

In the theoretical model, the effort to define the hypothesis and relational propositions from the emerged theory is essential (Strauss \& Corbin, 2008). Therefore, analyzing the relations between the macrocategories and the central category, some theoretical propositions about the model can be defined, as described below:

P1: The identity construction occurs in an environment marked by perceptions about whats it means to be vegan, interpretation about veganism, facilitators, barriers and representations of veganism in the media.

P2: The reflective consumption plays an important role on vegan identity construction, because it creates a reflection regarding ethical and moral questions related to consumption.

P3: Reflection on consumption is one of the main reasons of the conversion to veganism.

P4: Consumption is a way of keeping and assuring vegan identity and its image towards society.

Regarding the first proposition (P1), as described by Nunan (2003), identity is influenced by the situation in which the individual is. In addition, Farias et al (2019) highlight that the cultural context in which individuals are inserted influences the process of creating identity according to their group and differentiation in relation to other groups. Thus, it is observed that the context in which individuals are in is essential to the process of vegan identity construction. In addition to that, Farias et al (2019) states that situations experienced by subjects carry positive relations of inclusion and 
negative relations of exclusion. It can be noted that vegan identity construction occurs in an environment that sometimes acts on a positive note, that is, in order to reinforce the construction and assurance of this identity, and sometimes acts negatively, questioning vegan values and hiding the reality of violence and exploitation faced by animals.

The second proposition (P2) indicates that vegan identity construction goes through a reflection process, which has direct implications on the consumption behavior of the subjects. Therefore, it is noted that each individual takes into account their ethical and moral questions when consuming. Agreeing to this, Goig (2009) lectures about a kind of responsible consumption that has been gaining strength in the past years, where the new developed consumption culture is ruled by values of a more reflective nature, such as concerns regarding social responsibility, the environment and respect for human rights. It is also observed that veganism matches the idea of responsible consumption, when reflection on purchase actions generates a new type of consumptions, that is, reflective consumption, in which people reframe their actions, ruled by the concern about a fairer lifestyle for them, for the animals and for the whole planet. Thus, reflective consumption exercises a crucial role in the vegan identity construction.

Furthermore, the third proposition (P3) reinforces the idea that reflective consumption has a direct influence on the process of conversion to veganism. Kaminski (2010) already said that it is through their values that individuals seek through the act of consumption to differentiate themselves from certain social groups or to belong to a specific group, seeking at the same time differentiation and to stand out. Therefore, through reflection on consumption behavior, the individual can change and assume a distinct posture, according to the individual's values and beliefs.

Lastly, as presented in the fourth proposition (P4), it can be verified that consumption acts as a means of reinforcement to vegan identity, creating divergence regarding other people and helping with the maintenance of the group identity. Agreeing with that, Douglas and Isherwood (2004) state that a person can use the act of consumption to say something about oneself. Thus, the purchase of products that do not have animal origins and do not carry any traces of animal or human exploitation in their process of production is a way for vegans to reassure their identity. Therefore, the purchase of certain product becomes an important way of communicating the expression of one's "self" (Slater, 2002). Thus, consumption becomes something used to maintain and reassure vegan identity towards society.

\section{FINAL CONSIDERATIONS}

This research aimed to understand how the process of vegan identity construction through consumption occurs, which was made by conceiving a meta-synthesis of the studies found. At the end of the analysis, it was obtained a theoretical model composed of eight macrocategories that were interconnected to a central category, the Vegan Identity.

It was possible to note that Vegan Identity covers a new way of identification and behavior towards the contemporary society, with this being demonstrated either through consumption practices, interpersonal relationships, work or many other situations experienced by its supporters. Thuds, veganism becomes a lifestyle, or, according to Trigueiro (2013), a lifestyle, because it goes beyond an ephemeral change, that is, it represents a fight and the reframing of values and practices.

Therefore, is was observed that reflective consumption is one of the main factors of vegan identity construction, as the adoption of the vegan lifestyle imposes to its adepts the need to act consciously towards their actions. That means that through their acts of consumption the ethical and moral considerations defended by the vegan movement are transformed, truly, into practical actions, that is, it is the way of consuming that differentiates the vegans from other groups and allows, at the same time, the construction and assertion of their identity.

In addition, the present study intended to contribute to the knowledge about vegan consumer behavior, in order to collaborate to a better understanding of culture, consumption and processes of individual identification, besides contributing to publicize veganism, its propositions and demands. Therefore, using the meta-synthesis method contributed significantly, as it acts synthesizing and 
integrating the results of qualitative studies, in order to generate contributions that go beyond those already achieved by individual studies (Thorne et al., 2004).

It is important, however, to highlight a possible limitation: the fact that, although there is a lack of scientific papers on the studied subject, there are possibly other studies that approached the theme and, somehow, identified the relations between vegans and consumption practices that may not have been listed, either because of where the searches were made or even because of terms chosen. Another limiting factor is the fact that quantitative studies were not chosen, as the meta-synthesis approach was strictly followed.

Lastly, it is expected that this research contributes to future studies to be done with the purpose of comprehending even better the relation between consumption and veganism, so that the demands of this new group can be truly answered by organizations. It is also expected that this paper can contribute as a model of meta-synthesis application on academic studies, in order to help other researchers who might be interested in following such approach.

\section{References}

Abonizio, J. (2013). Consumo alimentar e anticonsumismo: veganos e freeganos.Ciências Sociais Unisinos, 49(2), 191-196.

Acevedo, C. R., Tamashiro, H., Ramuski, C. L., Acevedo, M. M., Campo, I., \& Catão B. (2019). Motivação, valores e sentimentos por trás da resistência ao consumo e veganismo. Brazilian Journal of Development, 5(8), 12979-13004.

Beardsworth, A. D., \& Keil, E. T. (1991). Vegetarianism, veganism, and meat avoidance: Recent trends and findings. British Food Journal, 93(4), 19-24.

Belk, R. (1988). Possessions and the extended self. Journal of Consumer Research, 5(2), 139-167.

Belk, R. (2010). Sharing. Journal of Consumer Research, 36(5), 715-734.

Buttny, R., \& Kinefuchi, E. (2020). Vegans' problem stories: Negotiating vegan identity in dealing with omnivores. Discourse \& Society, 31(6), 1-19.

Canclini, N. G. (1999). Consumidores e cidadãos: conflitos multiculturais da globalização. In Consumidores e cidadãos: conflitos multiculturais da globalização. Rio de Janeiro, RJ: Editora UFRJ.

Cherry, E. (2006). Veganism as a cultural movement: A relational approach. Social Movement Studies, 5(2), 155-170.

DaSilva, G., Hecquet, J., \& King, K. (2019). Exploring veganism through serious leisure and liquid modernity. Annals of Leisure Research, 1-18.

Dermody, J., Koenig-Lewis, N., Zhao, A., \& Hanmer- Lloyd, S. (2018). Appraising the influence of proenvironmental self-identity on sustainable consumption buying and curtailment in emerging markets: Evidence from China and Poland. Journal of Business Research, 86, 333-343.

Douglas, M., \& Isherwood, B. (2004). $O$ mundo dos bens: para uma antropologia do consumo. Rio de Janeiro, RJ: Editora UFRJ.

Doyle, J. (2016). Celebrity vegans and the lifestyling of ethical consumption. Environmental Communication, 10(6), 777-790.

Farias, M. L., Sousa Júnior, J. H., Silva, B. G. F., \& Alcoforado, D. G. (2019). Compreendendo o Domínio "Projetos de Identidade do Consumidor": Revisão de literatura considerando a produção científica brasileira. Consumer Behavior Review, 3(2), 85-98.

Gabriel, Y., \& Lang, T. (2006). The Unmanageable Consumer. London: SAGE Publications.

Goig, R. L. (2009). Consumo responsable y globalización reflexiva: un estudio referido al comercio justo en España. Revista Española del Tercer Sector, 1(11), 145-165.

Greenebaum, J. (2012). Veganism, identity and the quest for authenticity. Food, Culture \& Society, 15(1), 129-144.

Kaminski, E. (2010). Consumo: uma construção identitária cultural na sociedade contemporânea. Revista de Estudos da Comunicação, 11(24). 
Lundahl, O. (2020) Dynamics of positive deviance in destigmatisation: celebrities and the media in the rise of veganism. Consumption Markets \& Culture, 23(3), 241-271.

Markowski, K. L., \& Roxburgh, S. (2019). "If I became a vegan, my family and friends would hate me:" Anticipating vegan stigma as a barrier to plant-based diets. Appetite, 135, 1-9.

McCracken, G. (2003). Cultura \& consumo. Rio de Janeiro, RJ: Mauad Editora Ltda.

Moreira, I. P. C., \& Acevedo, C. R. (2015). Resistance to consumption and Veganism: A Study about Motivations, Values, and Feelings. Revista Gestão \& Tecnologia, 15(2), 50-67.

Nunan, A. (2003). Homossexualidade: do preconceito aos padrões de consumo. Rio de Janeiro, RJ: Caravansarai.

Pereira, B., Ayrosa, E. A. T., \& Ojima, S. (2006). Consumo entre gays: compreendendo a construção da identidade homossexual através do consumo. Cadernos EBAPE, 4(2), 1-16.

Ribeiro, B. P. (2019). Impactos Psicossociais da Adoção do Veganismo. 39 f. Trabalho de Conclusão de Curso (Graduação em Psicologia) - Universidade Federal de Uberlândia, Uberlândia.

Rocha-Pinto, P. G. H. da (2006). Mercados de devoção: Consumo e identidades religiosas nos santuários de peregrinação xiita na Síria. Cultura, consumo e identidade, 167.

Rosa, A. P. da, \& Staldoni, L. S. (2016). O caso do Portal Vista-se: Midiatização e Sociedade em Rede. Rizoma, 4(2), 37-49.

Sandelowski, M., \& Barroso, J. (2006). Handbook for synthesizing qualitative research. New York, NY: Springer Publishing Company.

Santos, A., \& Fonseca, R. P. (2012). Realidades e imagens do especismo: impactos da indústria (agro) pecuária e representações publicitárias de animais não-humanos sencientes. Sociologia, 23, 205222.

Singer, P. Libertação animal. São Paulo, SP: Ed. WMF Martins Fontes, 2010.

Slater, D. (2002). Cultura do consumo \& modernidade. São Paulo, SP: Nobel, 2002.

Sneijder, P., \& Te Molder, H. (2009). Normalizing ideological food choice and eating practices. Identity work in online discussions on veganism. Appetite, 52(3), 621-630.

Strauss, A., \& Corbin, J. M. (2008). Pesquisa qualitativa: técnicas e procedimentos para o desenvolvimento de teoria fundamentada. Porto Alegre, RS: Artmed, 2008.

SVB - Sociedade Vegetariana Brasileira (2019). Mercado Vegetariano: Estimativa de Porcentagem de Vegetarianos $e$ Veganos no Brasil. Recuperado de: https://www.svb.org.br/vegetarianismo1/mercado-vegetariano.

SVB - Sociedade Vegetariana Brasileira (2020). Vegetarianismo. Recuperado de: https://svb.org.br/vegetarianismo1/o-que-e.

The Vegan Society (2020). Definition of veganism. Recuperado de: https://www.vegansociety.com/govegan/definition-veganism.

Thorne, S., Jensen, L., Kearney, M. H., Noblit, G., \& Sandelowski, M. (2004). Qualitative metasynthesis: reflections on methodological orientation and ideological agenda. Qualitative Health Research, 14(10), 1342-1365.

Trigueiro, A. (2013). Consumo, ética e natureza: o veganismo e as interfaces de uma política de vida. Revista Internacional Interdisciplinar INTERthesis, 10(1), 237-260. 